\title{
Border agglomerations in the Baltic area: obstacles and possibilities for local interaction
}

\author{
Thomas Lundén, Huddinge
}

\section{Introduction}

Border agglomerations can be defined as urban areas divided by a boundary separating independent states. Three cases of boundary agglomerations in the Baltic region have been chosen for this study: HaparandaTornio, Valga/Valka and Narva-Ivangorod. Not only do these agglomerations diverge in their history and present context, they also represent very different situations ranging from a western to an eastern EU internal border situation to a EU-/non-EU border constellation. In the case of Haparanda-Tornio, an old state boundary divides a border agglomeration with a very homogeneous population on one side and a mixed but partly interrelated one on the other. Valga/Valka is an example of relative equality between the border partners but the state boundary is recent. Both sides appear to find their Russian immigrant population challenging in similar ways. In Narva-Ivangorod, the common Russian-speaking ethnie is a minority on one side of the border and part of the majority on the other side. In the light of further EU expansion, the future of the border agglomerations will most likely be affected in different ways. Whereas the admission of Estonia and Latvia to the EU is expected to lead to the further integration of the two internal border study cases, the co-operation initiatives of the outer border case are expected to decrease. The aim of this article is to evaluate the factors that influence the spatial behaviour of border agglomeration inhabitants and to relate them to the geopolitical situation.

\section{Boundary theory as part of (inter)action theory}

With the re-emergence of Political Geography a few decades ago, a new emphasis was put on trans-boundary communication and the role of the individual in relation to the territorial state, especially at open boundaries (LUNDÉN 1973 for Norway-Sweden; REYNOLDS \& McNulty 1968 for Canada-USA). The discussion here on spatial behaviour in border towns therefore begins with an analysis of general factors influencing the individual's environment, continues with a discussion of the individuals' options for movement and contacts given a specific environment, and then puts individual and environment together under the given condition of a state boundary.
A number of interacting factors form the environment, thus influencing the actual movement and contact pattern of individuals (LUNDÉN 2001):

- Physical and biological environment: the physical landscape as a resource and the natural laws of e.g. reproduction, ageing, corporeal movement.

- Technical infrastructure: the man-made landscape of artefacts extending but also differentiating human reach.

- Regulation: the array of laws and other delimiting societal forces in the most visible way through border controls, but also in more general ways (e.g. age limits, censorship).

- Economy: or the evaluation of resources in society. Unlike technology and regulation, economy is, in principle, boundless.

- Culture: the evaluation of norms and traditions in society, including norms on family formation, upbringing of children, group relations and ethics (religion). While cultural norms have no clear boundaries, much of group formation (networks) are characterised by boundary-drawing (in-group - out-group) (BARTH 1969; Migdal 2004).

- Communication: or the spread of information in society, especially its reception and its effects. Language, in terms of actual comprehension but also as a symbol plays an important role in the boundary formation of individuals.

The state is a territorial, mostly hierarchical, regulatory organisation, claiming monopoly on the use of force within its domain. It supplies services to its members (citizens and/or residents), such as the provision of infrastructure, protection and education. In response, it demands loyalty, membership fees (taxation) and certain services (e.g. military and civil defence efforts). In certain respects, the independent state strives at homogeneity over its territory, especially the validity of its laws and the rights and responsibilities of the domain dwellers, in most cases equal to the citizens of the state. In most states, however, there is some hierarchy of local self-determination under the general umbrella of state legislation, but local autonomy differs from one state to the other.

The individual living in a certain state and in a certain location is partially influenced by the state and its territory of authority. In some ways, this is taken for granted, in other situations, the state authority is questioned. As pointed out by DeUTSCH (1953), a successful «nation state», that is a state where its inhabitants see them- 
selves as loyal to the idea of that state, makes the citizens faithful participants in the social communication of the state (LUNDÉN 2001). Language obviously plays an important role in this communication (LUNDÉN 2006). A «nationalising state» (BRUBAKER 1996) will use the language of the «nation» (in the sense of the stateforming people) both for direct communication with its inhabitants, but also as a symbol of something uniting the population, often at the expense of autochthonous language minorities and immigrant groups.

The individual is a creature with biological, social and economical needs and desires, related to the physical and social environment as stated above. As many of these needs and desires have a localised supply, the individuals have to relate to the surrounding world by moving, forming daily, annual and life-time trajectories in time-space (HägerSTRAND 1975). The individual contact and movement field is composed of voluntary acts, such as meeting friends and going shopping and mandatory acts, such as going to school, making military service and paying taxes to the state and/or to the local municipality. In the everyday life of most people and under ordinary conditions, acts, contacts and movements are a mixture of individual decisions, biological necessities and involuntary acts, imposed either by the State and its organisations, or by «social compulsion», e.g. family matters and cultural norms. Different people have different needs and desires but also different constraints in fulfilling their chores and wishes. ButTIMER speaks about the reach, the individual range of contacts and movements, usually centred on the home (Butrimer 1978). As pointed out by e.g. SCHACK, different groups may form different networks creating separate "regions», but within each group there will also be different networks depending on the type of action or communication, e.g. economical, regulation, social or cultural (SCHACK 2000: 204ff.). But as indicated in HäGERSTRAND's Time Geography, different types of individual and joint projects have to fit into the time and space restrictions of the individual life lines, and different types of networks therefore influence each other (LUNDÉN 2001).

WAACK (1999: 107) follows KEMPER (1980) in the differentiation between homogenizing and nearness principles, the first uniting kin or similarity irrespective of distance, the other obviously based on proximity. In HäGERSTRAND's words:

«Every large group of human beings is subjected to a tension between two principles of integration. We may conveniently call them the territorial and the functional modes. In the territorial mode of integration nearness is the supreme category and therefore thinking, loyalty and action become highly place-bound. Conflicts arise across geographical boundaries between neighbouring groups. In the functional mode of integration, $[\ldots]$ similarity is the supreme category. Thinking, loyalty and action become of a «non-places kind and unite what is similar in function over wide geographical areas. Critical boundaries emerge between interest groups, whether these are made up of subsets of the population or of professionals in competing sectors» (HÄGERSTRAND 1986: 8 ).

In the individual's choice of life line, the state territory and its organisational and behavioural implications play a particularly important role in an area cut by a state boundary (LUNDÉN 2004; LUNDÉN \& ZaLAMANS 2001). The spatial behaviour of the boundary town dweller is influenced by a number of localised supplies and services, and by their relative attractiveness and cost (in time and money). The freedom of movement and contacts is further influenced by the state of residence and the state of citizenship, as well as by the linguistic and social competence of the inhabitants. The culture of searching and evaluating possibilities and choosing life paths is furthermore an important determinant of how people meet and how contacts are formed.

These factors work in time and space as contending and co-operating pressures on individuals forming their life paths. The boundary town represents a very special case where the «national» idea of an unquestioned allegiance to the state and its territory can be questioned. While some of the factors mentioned above will work in favour of a homogenous state territory with no supplies or attractions outside its boundaries, others will emphasise proximities to supplies and attractions beyond that territory. Obviously the regulation factor, including state laws, the election system and boundary controls will mostly work in favour of the state of domicile. Technical infrastructure is moreover often attuned to the state territory. Economic and communication factors have no boundaries, in principle, but in reality they are often restricted by regulation. Furthermore, through the «national» systems of education and mass communication, there is an influence on culture that may work in favour of the state of residence. In people's minds, boundaries, physical and mental, serve as «checkpoints and mental maps. Boundaries are constructed through the practical monitoring devices that groups use to differentiate members and to enforce separation" (MIGDAL 2004: 7).

It is the relation between the physical boundary and the barrier function in the individual's pattern of contacts and movements that the following examples are examined.

\section{Northern Europe: Haparanda and Tornio}

The neighbouring towns of Haparanda and Tornio, separated only by a short land boundary between Finland and Sweden at the mouth of the Torne River (Fig. 1), 


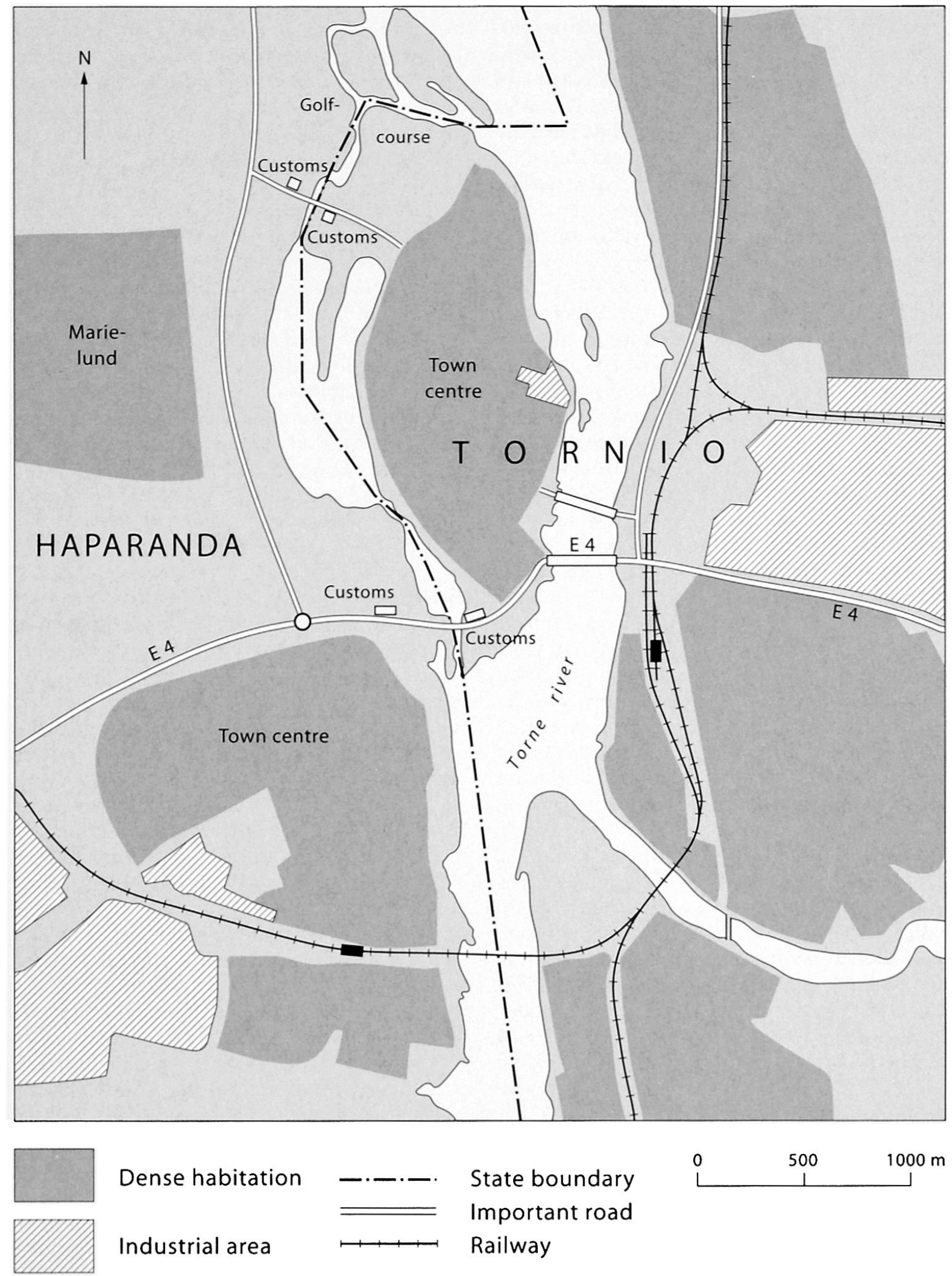

Fig. 1: Map of Haparanda-Tornio

The new IKEA furniture shop, opened in November 2006, is located near the customs border control on the Swedish side. Further commercial and administrative developments will fill the empty space between the two town centres.

Karte von Haparanda-Tornio

Carte de Haparanda-Tornio

Cartography: L. BAUMANN 
have a population of about 10000 and 23000 , respectively. While the state boundary was superimposed on Tornio in 1809, Haparanda arose as a result of the new territorial split. The western boundary of Haparanda municipality coincides with the old linguistic boundary of Finnish towards Swedish. In terms of culture as defined above, the population of the transboundary area can be said to be composed of four groups (Lundén \& Zalamans 2001). Due to the lack of ethnic census in Sweden, but also due to the sliding scale of ethnic belonging, there are no relevant figures for the numbers of each group.

Finland Finns, living in Tornio and on the eastern side of the river, speak Finnish, and mostly have no or little knowledge of Swedish.

Sweden Swedes, living mainly in the urban area of Haparanda municipality, are either descendants of the urban settlers from Southern Sweden or have come to the area to work as e.g. officials, teachers. They generally have no or little knowledge of Finnish.

Torne Valley inhabitants on the Swedish side speak Swedish and more or less fluently, Finnish, the original language of the region. Torne Valley inhabitants (in Sweden) usually have kinship and friendship contacts on both sides of the boundary.

Sweden Finns, living in the urban area of Haparanda are mostly immigrants from Northern Finland who have settled in Haparanda after having lived in Southern Sweden as labourers. Many of them have little or no skill in speaking Swedish, and their capability of reading Swedish may also be low. Their reason for moving to Haparanda seems to be to keep some advantages such as social benefits and lower housing costs. By having their homestead just a few hundred metres from the boundary, it would appear that they place great emphasis in preserving their Finnishness and contacts with Finland.

\subsection{Physical and infrastructural environment}

Natural conditions and the lack of border controls favour an amalgamation of the two towns. There is a successful co-operation between the towns of Haparanda and Tornio including language schools, open to pupils from both sides, a common circle bus line, fire, rescue and ambulance co-operation, agreements on joint district heating networks and deliveries of water across the state boundary. While sports are usually carried out within each country's hierarchic system, the two towns share much of the sports and recreation infrastructures, including a trans-boundary golf course and a so-called walking Path of Health. While for example, certain aspects of medical and health care in Sweden are the responsibility of the County Councils (Lands- ting), in Finland this is taken care of by municipalities. In spite of this, the two bodies co-operate in utilising expensive equipment, specialists and ambulance services.

\subsection{Attitudes, identities and voting behaviour}

Within the research project «Boundaries to communication» a large questionnaire survey was conducted during the summer of 1999 , with a response rate of about $70 \%$ (Zalamans 2001). As the respondents were chosen through a random sample of the population register of each municipality, the survey is considered to be statistically representative for the inhabitants aged between 18 and 69 years of Haparanda and Tornio.

There are conspicuous differences in the use of media between the inhabitants of Haparanda and Tornio. Each town is dominated by newspapers issued for the province in either Finland or Sweden, and in the majority language of each state. The local Tornio paper is quite frequently read by the Sweden Finns. This group also frequently listen to a local station of the Finland side, and they also watch Finnish television channels (ZaLamans 2001).

About $90 \%$ of all respondents cross the boundary at least once a month, the main reason being shopping and contacts with relatives and/or friends. In Haparanda and Tornio about half of respondents have relatives on the other side, and some $70 \%$ have friends there. While around $25 \%$ of the respondents in Haparanda and Tornio participate in an organisation or Non-Governmental Organisation (NGO), they mostly do it in their own town.

There is some dissimilarity between the inhabitants as regards the perception of «the other». In Haparanda, $36 \%$ mentioned there are differences between the inhabitants in Haparanda and Tornio and that there is a «we and they» mentality, while the equivalent figure for Tornio is $23 \%$. Generally, the inhabitants of Tornio are more positive in their opinions of their neighbours than those of Haparanda. Those in Haparanda who are most negative to their neighbours are Swedes with little or no knowledge of Finnish.

Studies of the future plans of teenagers in both towns indicate a low degree of willingness to stay in the area, an almost total lack of interest in moving over to the other town, but rather vague dreams of a future in the capital of the respective countries, or - the only thing that unites the two groups - in some international metropolis (JukARAINEN 2001).

In 2000, the towns presented a plan for development of Tornio and Haparanda, implying a common devel- 
opment of the boundary zone into a commercial and administrative centre for both cities, the state boundary running right through the centre. This plan was the object of a local referendum in Haparanda in connection with the general elections of September 2002. Much to the surprise of the local politicians, the proposal was turned down by a slight majority of a low voting turnout. In voting districts with low overall turnout, yes-votes dominate and vice versa. This indicates that Finnish residents, who have a low tendency to vote, turn to a positive vote, whereas Swedish residents, with a higher turnout, tend to react negatively to the project proposal (election results, Haparanda municipality). In the September 17, 2006, election in Sweden, the Haparanda result was exceptional in comparison with other Swedish municipalities: The Social Democrats increased their majority from 45 to $61 \%$, quite contrary to the national trend, while the voting turnout was - as usual - by far the lowest in Sweden, $59,53 \%$ compared to the average of approximately $80 \%$ (VALmYNDIGHETEN 2006). The party vote was probably a reflection of an external decision - the establishment of a new IKEA furniture store in the municipality - which helped the reigning party. The low voting turnout is clearly related to the citizens of Finland who are entitled to vote in local elections but who show an equally low interest in both Swedish and local municipality politics. This, in turn, is an indication of a different pattern of contacts and movements compared to the two other groups of inhabitants of the Swedish town.

\section{EU - Russia: Narva-Ivangorod}

Narva is a town of approximately 70000 inhabitants on the western bank of the Narva River in north-eastern Estonia. On the eastern bank of the Narva river is Ivangorod with 10000 inhabitants (Fig. 2). At the re-establishment of the Estonian Soviet Republic in 1944, ethnic Russians and other ethnic groups from the Soviet Union replaced the original population, resulting in an almost total russification of the language use in Narva and the rest of the Ida-Virumaa province. In 1991, Estonia reappeared as an independent state and de facto, the Narva River became the north-eastern boundary to the Russian Federation. With the economic decline of Russia and the increasing difficulty to maintain contact with Narva, Ivangorod lost almost all its industry. Narva was also severely affected by the collapse of the centrally planned economy (BERG 1999a, 1999b; BRÜGgEMANN 2005; LUNDÉN \& ZaLAMANS 2000, 2002; SMITH 2002).

\subsection{Infrastructure}

The Narva River is a clear dividing line, but there is a highway, a railway and a pedestrian bridge linking the two towns. With the new Estonian legislation in Narva, urban planning was catered for. However, a foundation was not laid for co-operation with Ivangorod in this regard. Narva is supplied with water and sewerage from a local plant that also used to supply Ivangorod. After repeated reminders of payment dues, the local water supplier cut off supplies to Ivangorod in November 1998. Soon after, even sewerage and purification was cut off. The effluents from Ivangorod were consequently dispersed directly into the river. This situation has somewhat been eased with most industries on the Russian side now idle. Furthermore, a new plant has been built with financial support from Denmark.

The Narva hospital has no contact with its crossborder counterpart. On the Russian side, hospitals receive a good number of Russian citizens from Estonia for treatment, as they have a right to free care. Within the Estonian system, non-citizens are requested to pay a substantial fee for health care insurance. This, together with other real and imagined benefits, explains why so many Russians in Narva have decided to keep their Russian citizenship. However, as Ivangorod carries the financial burden, this situation has added to crossborder tensions.

\subsection{Social conditions}

In Narva today, family life is almost totally absent from public affairs. After independence, a great number of families were "split» as one parent was officially registered on the "wrong" side of the boundary, but most cases have now been resolved.

Before Estonia's independence in 1991, the employment market was dictated by central plans. Workers were almost always recruited from outside Estonia, mostly from Russia. Production units «owned» housing and recreation establishments. As the employees «belonged» more to the production units than to the municipalities, it did not matter in which area they lived. The Krenholm textile plant, for example, had a pedestrian bridge that connected it with the Russian side of the agglomeration, evidently for part of their workers. Partly due to the establishment of the state boundary and partly to the layoffs at Krenholm, the number of employees living on the other side has dwindled to almost nil.

Available statistics show that violent crime is overrepresented in the north-eastern parts of Estonia. This is not unexpected for an area with border traffic, high unemployment and a class structure characterised by certain types of «visible» crime. During Soviet times, released criminals were often deported to areas away from their homes. Narva was just beyond the Leningrad oblast and was, for this reason, an attractive deportation destination. 


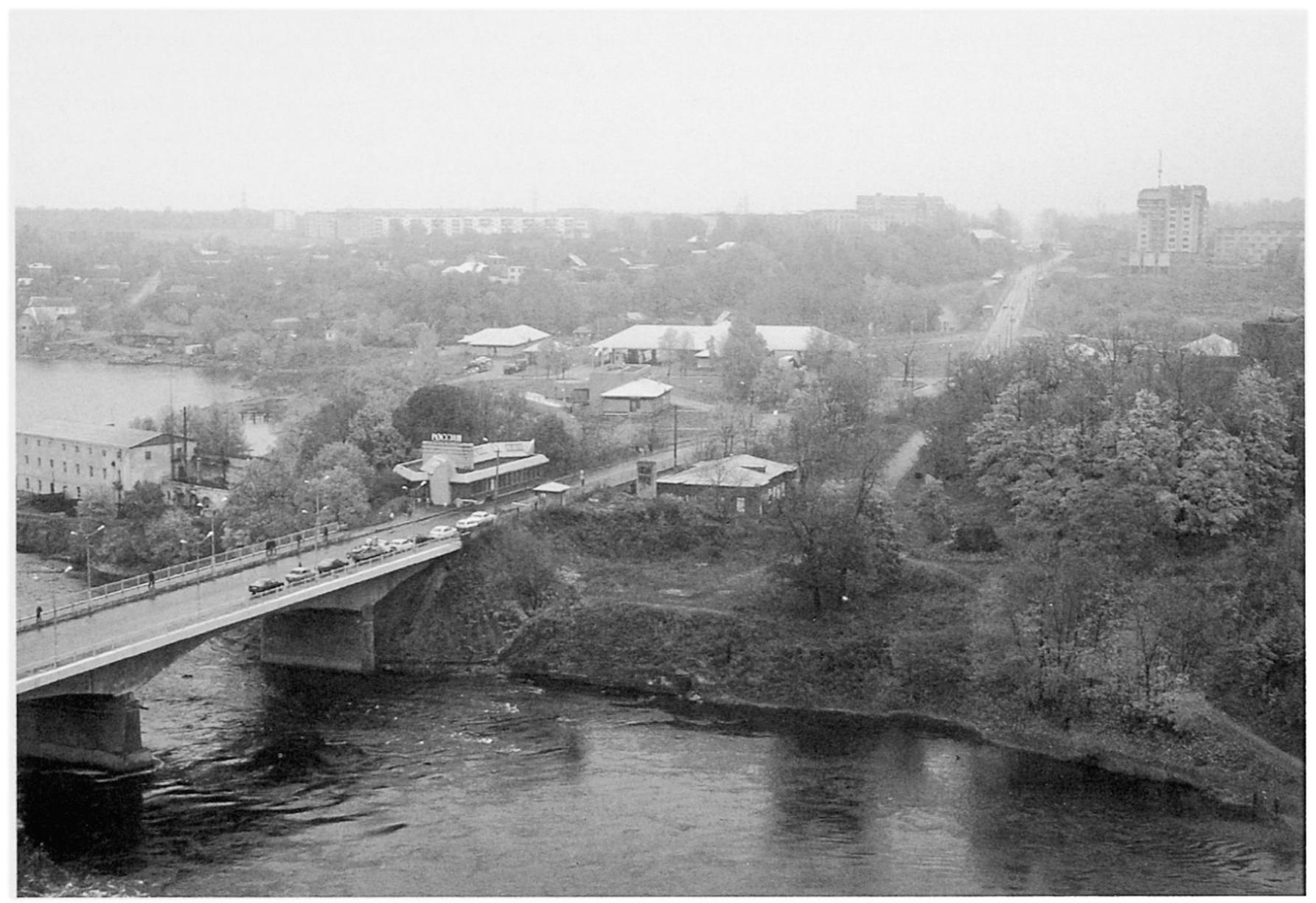

Fig. 2: The Russian border control and Ivangorod as seen from Narva Der russische Grenzposten und Ivangorod von Narva aus gesehen Le poste-frontière russe et Ivangorod vus de Narva Photo: T. LUNDÉn 2000

\subsection{Citizenship}

The inhabitants of Narva can be divided into three rather equal categories according to citizenship: some $40 \%$ having acquired Estonian citizenship, $31 \%$ are Russian citizens, while the remainder are considered aliens who require a special permit which was until recently also valid for crossing the boundary. Many Narvaites do not see the advantage of acquiring Estonian citizenship as citizens of Russia have a right to free basic medical care in Ivangorod, and boundary passage has, until recently, been facilitated by being a citizen of Russia. With the accession of Estonia to the EU, standard visas are now required. «Aliens» are required to apply for working and residence permits, and the application procedure is slow and tedious. An alien's action radius is limited; it is difficult to travel abroad, to invite relatives to Estonia, to do business and to acquire land in border areas (including, of course, in the Narva area) (LUNDÉn \& Zalamans 2000, 2002).

\subsection{Mass media consumption}

The population of Narva have, in principle, access to media from Estonia and from Russia, in Estonian and Russian. Most people watch TV from Russia, including the news. Local Narva radio stations mostly send in Russian and try to also cover news from Ivangorod. Narva has some local newspapers, all in Russian, but the younger generation does not usually read them.

\subsection{Attitudes}

Narva politicians wholly accept Estonia, but complain that the Central Government not only ignores their region, but treats the Estonia Russians as an «alien mass». Narvaites in intellectual positions have repeatedly strongly criticised the language legislation, which they see as an oppression of minority rights.

Young people are far more positive about Estonia than the generation of their parents. There is only one school in Narva for Estonian native speakers. All 
schools have begun teaching in Estonian, but there is a great lack of language teachers. There is no co-operation with schools in Ivangorod. Most young people speak Russian with each other; the very few Estonian speakers live in an environment where they still have to speak Russian most of the time. The attitude towards Estonia is, however, mainly positive - «we were born here». Few young people want to stay in Narva, they want to "go west», very few see Russia as an alternative, but Estonia is not very attractive either.

In the winter of 2003/04, 93 pupils, aged sixteen to twenty from three secondary schools in Narva, including the only Estonian school, were questioned about their ethnic and citizenship origin and their preferences concerning the boundary and the border area (Zalamans 2006). Due to the method and the choice of samples, the results can only be interpreted as an indication of the situation. In the Estonian school, $90 \%$ of pupils are Estonian citizens. In the Russian school, $54 \%$ are Estonian citizens, $17 \%$ are Russian and $29 \%$ are «alien». In terms of (ethnic) nationality, $78 \%$ in the Estonian school claim to be of Estonian ethnie, while most of the remainder gave no answer. In the Russian schools, $90 \%$ claim to be of Russian origin. In terms of home language, in Russian schools almost $100 \%$ use Russian, while the pupils in the Estonian school tend to have more of a bilingual background. Almost half of these pupils profess at being fluent in Estonian and very good in Russian. While most pupils have relatives in the neighbouring country (i.e. Russia), only Russian school pupils have friends there. However, very few have friends in the twin town over the border. Few cross the boundary regularly. Of the groups that cross, Russian pupils cross more often and usually because of relatives.

When asked if they saw any difference between them and their twin town, about half of the Russian school pupils felt there was a difference, and the other half felt there wasn't. In contrast, Estonian pupils mostly refrained from answering the question. This could be because they have no experience of Ivangorod. Asked if the boundary was seen as «good» or «bad», the Estonian response emphasised their attitude of the boundary being a form of protection. Russian pupils were again equally divided with this question. Estonian pupils in particular felt that their town had a very bad image in the country, although a feeling of negative image is shared by most pupils.

\section{Baltic Europe: Valga/Valka}

Valga (Estonia) and Valka (Latvia) are legally two towns but morphologically and, partly functionally, they constitute one unit separated by the state boundary (Fig. 3). As a junction on the Tallinn-Riga and Pskov-Riga railway lines, it attracted a population of ethnic Estonians, Latvians and Russians. With the independence of Estonia and Latvia in 1920, the town was divided between the two states, mainly on ethnic grounds. The solution was to draw the boundary almost in the middle of the small town (KANT 1932). With the Soviet annexation, the town for practical reasons became united again, although divided between two Soviet republics. With the independence of Estonia and Latvia in 1991, Valga/Valka again became a divided town, of 15000 and 7500 inhabitants respectively (LUNDÉN \& ZaLAMANS 2002).

\subsection{Public administration and education}

During Soviet rule, Valga/Valka functioned as one city in areas such as health care, planning and development of infrastructure. During the first years of independence there was no co-operation at all. Drawing on experiences made by the Haparanda-Tornio administrations, Valga and Valka initiated a common programme of networking. In spite of this, there are several areas in which each city functions independently. Health care, for example, is strictly connected to the country where the patient lives. Both towns have had problems with quality of drinking water and both recently constructed their own sewage-treatment plant. The size of each plant is big enough to serve both towns. There are Russian speaking schools in Valga and Valka, with good contacts with the majority schools on the same side. Contacts between schools over the state boundary are rare between Estonian and Latvian speaking schools but, evidently, non-existent between Russian speaking schools, which do not have contacts with other schools in Russia either.

\subsection{Commercial infrastructure}

According to the central-place theory (CHRISTALLER 1933; LoESCH 1944), Valga/Valka can either be seen as two separate shopping areas in a hierarchy within their respective states, or as one larger central place serving people from both sides of the boundary. In Valga/ Valka, the common centre has become a periphery as both sides are turning towards their capitals. Waiting time at the border and the real time it takes to move from one side to the other seem to be the major hindrances. Valga has both a wider choice of shopping and dining and in general lower prices, except for tobacco and alcohol. For shopping purposes, it is thus the inhabitants of Valka that cross the border more often.

\subsection{Media, culture and sports}

Even though Valga/Valka is a twin town situated on the border, there is no or little interest in the news of the neighbouring country. This is not only shown in the lack of media information but also in the attitudes of the persons interviewed. Valga has both a Russian 


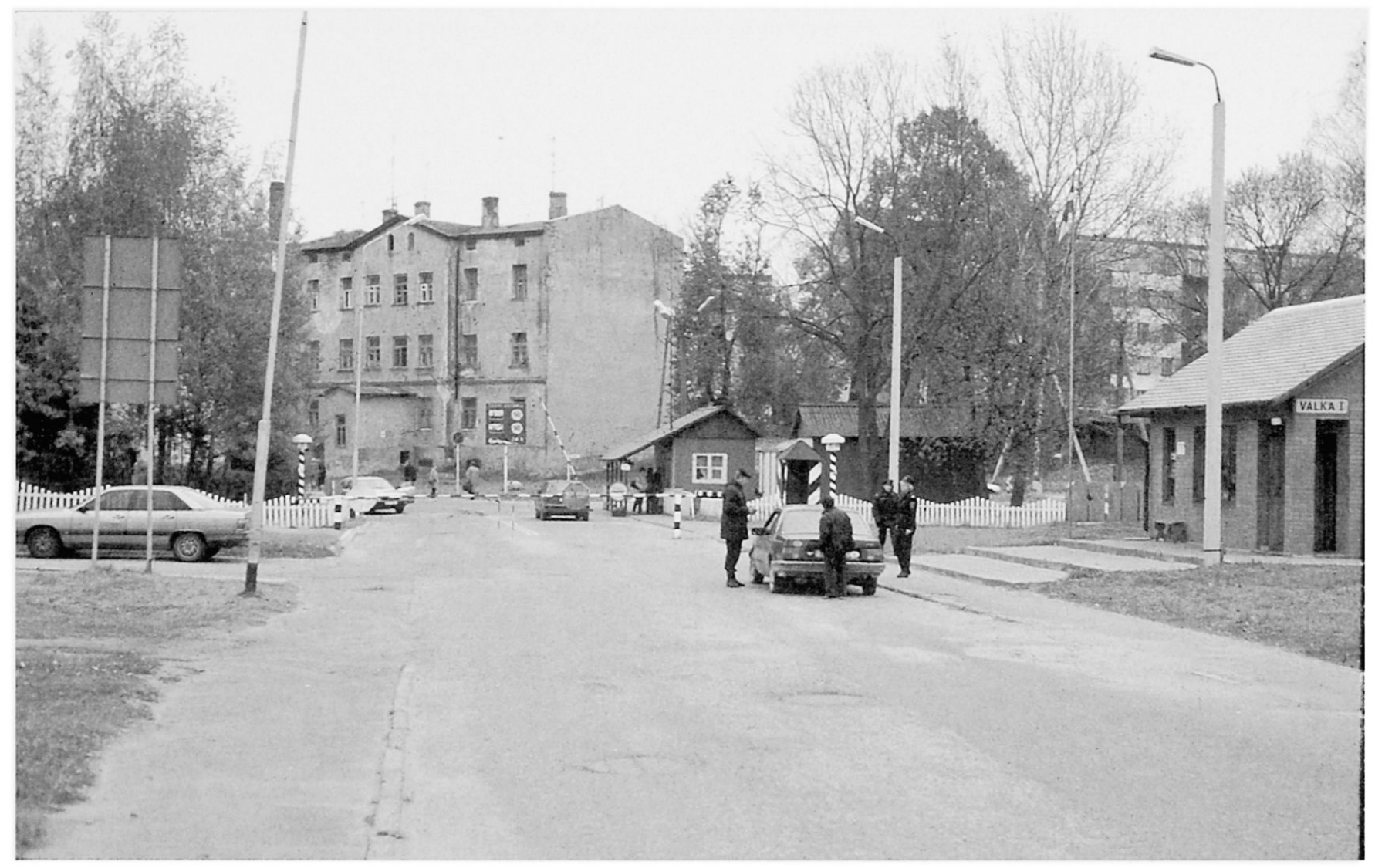

Fig. 3: The Valka/Valga border control as seen from Latvia towards Estonia, before the new EU arrangements Der Valka/Valga-Grenzposten von Lettland aus gesehen in Richtung Estland, vor den EU-Vereinbarungen Le poste-frontière de Valka/Valga vu de la Lituanie vers l'Estonie avant les accords de l'UE Photo: T. LUNDÉN 1999

Orthodox Church and Catholic Cathedral. On the other hand, several graveyards from Soviet times are located in Valka, with graves of ethnic Estonians, Russians and other nationalities. Before independence in 1991, it was quite common that both sport schools and sport clubs had members from both sides of the border. Today, Latvian pupils use to some extent the sport arena and the swimming pool in Valga. Besides language barriers and visa difficulties, border waiting time is a further hindrance to freer movement, especially for the non-citizens.

\subsection{Mobility, language communication and attitudes}

While inter-group relations are on the whole satisfactory, the language barrier is a major problem. Estonia and Latvia now have only one official language each. Even though all Estonians and Latvians above the age of twenty-five speak Russian more or less fluently, it is seldom used in conversation. During Soviet times, Estonian or Latvian were taught in the respective local Russian schools, but the teaching was not taken seriously. Today, it is essential to have a good knowledge of the language as well as of the state history and constitution to become an Estonian or Latvian citizen. For these and other reasons, a large part of the population in Valga $(\sim 40 \%)$ and Valka ( $25 \%)$ have not taken on citizenship of their states of residence.

In the winter of 2003/04, 43 pupils from the secondary schools in Valga (one Estonian and one Russian) were asked the same questions as Narva (Zalamans 2006). The sample of students was taken from several classes.

The results of the questionnaire indicated that the situation in Valga is quite different to that in Narva. All of the pupils of the Estonian school and $50 \%$ of the Russian school have Estonian citizenship, while most of the remainder are «aliens». Concerning ethnic nationality, $92 \%$ of the Estonian school and $13 \%$ of pupils of the Russian school claim Estonian nationality (the latter probably because of confusion with citizenship), while in the latter school $75 \%$ see themselves as ethnic Russians. In terms of language used at home, 


\begin{tabular}{|llll|}
\hline & Haparanda-Tornio & Narva-Ivangorod & Valga/Valka \\
Development & Stable & Stagnant/declining & Changeable \\
Political permeability & Great & Low & Variable \\
$\begin{array}{l}\text { Physical permeability } \\
\text { Ethnicity }\end{array}$ & Great & Low & Fair \\
$\begin{array}{l}\text { Ethnicity in relation to } \\
\text { state nation }\end{array}$ & Mixed/unit & Unit & Mixed \\
$\begin{array}{l}\text { Political transboundary } \\
\text { cooperation }\end{array}$ & Great & Divergent/unit & Unit/divergent \\
\hline
\end{tabular}

Tab. 1: Classification of the three Baltic border towns

Klassifikation der drei baltischen Grenzstädte

Classification des trois villes-frontières baltes

more than $90 \%$ use the "school language». However, clear differences are evident in terms of language skill: pupils of the Russian school profess an intermediate knowledge of Estonian, whereas the pupils from the Estonian school are much better at English than at Russian.

In the Russian school, almost all pupils have relatives $(94 \%)$ and friends $(81 \%)$ in the neighbouring state and town, while in the Estonian school there are far fewer connections ( $15 \%$ and $33 \%$, respectively). The Russians are frequent boundary crossers, in clear contrast to the Estonians. The main purpose given by the Russians for border crossing is for visiting friends and relatives; for the Estonians it is shopping. With regard to perception, most Valga pupils, especially the Russians, see little difference between their town and the twin town. They have vague but mostly positive ideas about their cross-boundary neighbours' perception of their home town. Not surprisingly, Russians (38\%) more than Estonians (11\%) see the boundary as something bad.

For ethnic Estonians and Latvians, there is little need to cross. The others (mostly Russian speakers) have a larger motivation for boundary crossing, while at the same time having greater difficulty. It is interesting that the Russian community on each side has no or little contact with each other at official levels, although it seems that they are the ones that pass the boundary most frequently on a private basis.

\section{Conclusions}

Three Baltic border towns: attempt at a classification. The three boundary agglomerations selected for study can be characterized according to development, political permeability, physical permeability, ethnicity, ethnicity in relation to state nation, and to political transboundary co-operation (Tab. 1).

For Haparanda-Tornio, the division into two states has created substantial differences between the two towns. Of the four major population groups, two seem to be able to use the opportunities on both sides: The Sweden Finns, who benefit from some advantages from living in Sweden while using social, cultural and commercial networks on the Finnish side, and the autochthonous Torne Valley population in Sweden, who can use their (relative) bilingualism for contacts on both sides. For the two remaining groups, the boundary to some extent deprives them of half of their action space.

In the case of Narva and Ivangorod, obstacles are so great that co-operation is practically impossible, in spite of a common local language and a common history - or perhaps just because of that.

Compared to other twin towns in Europe, Valga/Valka is unique because of a rather clear division of nationalities between the two majority populations, but with a strong minority of ethnic Russians on both sides. To most inhabitants of the towns, the boundary seems to be of little hindrance as they see very few opportunities on the other side. The reports indicate, however, several difficulties: In most cases, local intentions clash with state legislation and with policies for the «nationalisation» of each country. The Russian speakers seem to be the only group that really has a contact network across the boundary.

\section{Literature}

BARTH, F. (1969): Ethnic groups and boundaries. The social organization of culture difference. - Oslo: Universitetsforlaget.

BERG, E. (1999a): Estonia's northeastern periphery 
in politics. Socio-economic and ethnic dimensions. - Tartu: Tartu University.

BERG, E. (ed.) (1999b): Common border, shared problems. The Estonian - Russian Border. - Tartu: Center for Transboundary Cooperation.

BRUbakeR, R. (1996): Nationalism reframed. Nationhood and the national question in the new Europe. - Cambridge: Cambridge University Press.

BRÜGgEMANN, K. (2005): Narva. Ein Erinnerungsort der estnischen und russischen Geschichte. - In: Angermann, N., GarlefF, M. \& W. Lenz (Hrsg.): Ostseeprovinzen, Baltische Staaten und das Nationale. Festschrift für Gert von Pistohlkors zum 70. Geburtstag. - Schriften der Baltischen Historischen Kommission 14, Münster: Lit Verlag: 635-661.

Buttimer, A. (1978): Home, reach and the sense of place. - In: Aldskogius, H. (red.): Regional identitet och förändring i den regionala samverkans samhälle. Föredrag och diskussioner vid Kulturgeografiska institutionens vid Uppsala universitet symposium 1-3 december 1977. - Symposia Universitatis Upsaliensis Annum Quigentesimum Celbrantis 11, Uppsala: 13-40. Christaller, W. (1933): Die zentralen Orte in Süddeutschland. - Jena: Gustav Fischer.

DEUTSCH, K.W. (1953): Nationalism and social communication. - Cambridge, Mass., New York: MIT Press.

HäGERSTRAND, T. (1975): Space, time and human conditions. - In: KarlQvist, A., LuNDQvist, L. \& F. SNICKARS (eds): Dynamic allocation of urban space. - Farnborough, Hants.: Saxon House.

HäGERSTRAND, T. (1986): Decentralization and radio broadcasting. On the "possibility space» of a communication technology. - In: European journal of communication 1,7-26.

JUKARAINEN, P. (2001): Rauhan ja raudan rajoilla. Nuorten maailmanjäsenyyksiä Suomen ja Venäjän sekä Ruotsin ja Suomen rajojen tuntumassa. - Helsinki: Helsingin Yliopisto.

Kant, E. (1932): Valga. Geograafiline ja majanduse ülevade. - Tartu: Tartu Ülikool Majandusgeograafia Seminari Üllitised.

Kemper, F.-J. (1980): Aktionsräumliche Analyse der Sozialkontakte einer städtischen Bevölkerung. - In: Geographische Zeitschrift 68, 3: 199-222.

LOESCH, A. (1944): Die räumliche Ordnung der Wirtschaft. - Jena: Fischer Verlag.

LUNDÉN, T. (1973): Individens rumsliga beteende i ett gränsområde. - Stockholm: Stockholms Universitet Kulturgeografiska institutionen, Meddelande B 26.

Lundén, T. (2001): The domain in Time Geography. A focus on Political Geography. - In: Antonsich, M., Kolossov, V. \& M.P. Pagnini (eds): Europe between Political Geography and Geopolitics. - Memorie 63, Roma: Società Geografica Italiana: 269-277.

LundÉn, T. (2004): On the boundary. On human beings at the end of territory. - Stockholm, Huddinge: Läromedel från Södertörns högskola 2.
LUNDÉN, T. (2006): Language and communication proximity in border areas. - In: HuRD, M. (ed.): Borderland identities. Territory and belonging in North, Central and East Europe. - Baltic \& East European Studies 8, Eslöv, Huddinge: Södertörn University College: $147-162$.

Lundén, T. \& D. Zalamans (2000): Boundary towns. Studies of communications and boundaries in Estonia and its neighbours. - Kulturgeografiskt seminarium 2/00, Stockholm: Stockholm University, Department of Human Geography.

LundÉn, T. \& D. Zalamans (2001): Local co-operation, ethnic diversity and state territoriality - the case of Haparanda and Tornio on the Sweden - Finland border. - In: GeoJournal 54, 33-42.

LundÉN, T. \& D. Zalamans (2002): «National allegiance» and spatial behavior in Baltic boundary twin towns. - In: Journal of Baltic studies 33, 2: 177-198.

Migdal, J.S. (2004): Mental maps and virtual checkpoints. Struggles to construct and maintain state and social boundaries. - In: Migdal, J.S. (ed.): Boundaries and belonging. States and societies in the struggle to shape identities and local practices. - Cambridge: Cambridge University Press: 3-26.

Reynolds, D.E \& M. McNulty (1968): On the analysis of political boundaries as barriers. A perceptual approach. - In: East lakes geographer 4:21-38.

SCHACK, M. (2000): On the multicontextual character of border regions. - In: VAN DER VeLDE, M. \& H. vaN Hourum (eds): Borders, regions and people. - London: Pion: 202-219.

SMITH, D.J. (2002): Narva region within the Estonian Republic. From autonomism to accomodation? - In: Batr, J. \& K. Wolczuk (eds): Region, state and identity in Central and Eastern Europe. - London, Portland, Or.: Frank Cass: 89-110.

VALMYNDIGHETEN (2006): www.val.se 4.12.2006.

WAACK, C. (1999): Stadträume und Staatsgrenzen. - = Beiträge zur regionalen Geographie 51, Leipzig: Leibniz-Institut für Länderkunde.

Zalamans, D. (2001): Gränsen mellan grannstäder. In: RamiReZ, J.L. (ed.): Att forska om gränser. - Nordregio report 2001,3, Stockholm: Nordregio: 193-210.

Zalamans, D. (2006): On the margin. Youth in Narva and Valga on the Estonian border. - In: LUNDÉN, T. (ed.): Crossing the border. Boundary relations in a changing Europe. - Baltic and East European studies 9, Södertörn University College, Eslöv/Gdansk: Gondolin: 103-116.

\section{Summary: Border agglomerations in the Baltic area: obstacles and possibilities for local interaction} In order to evaluate the factors that influence the spatial behaviour of border agglomeration inhabitants and to relate them to the geopolitical situation, attention is given here to three divided towns in the Baltic 
Sea region: Haparanda-Tornio, Narva-Ivangorod and Valga/Valka. The three cases represent different geopolitical and ethnical configurations. Boundary theory is discussed as part of (inter)action theory, with particular emphasis on the homogenizing role of the state in contrast to the (inter)action possibilities of individuals living in a border area. In the Haparanda-Tornio study case, a homogenous population on the Finnish side is compared to a more diversified ethnic grouping in Haparanda, Sweden. Here, immigrants from Finland are seen to have an action space directed towards Finland, while bilingual locals act as bridge-builders. In Narva-Ivangorod, the same Russian ethnic group lives on both sides of the boundary, but geopolitical restrictions hamper local cross-boundary interaction. Valga/Valka, in contrast, is divided according to ethnic criteria. Little motivation for border crossing appears to be given, except for the Russian speaking population, which at the same time has the greatest formal difficulties in crossing. The internal European Union borders, both recent and older, thus allow ethnic and linguistic factors to influence the action and communication space of inhabitants. The EU/non-EU boundary restricts the possibilities of local cross-boundary interaction even in situations where the population belongs to the same ethnic group.

\section{Zusammenfassung: Grenzagglomerationen im Ost- seeraum: Hindernisse und Möglichkeiten für lokale Interaktion}

Anhand dreier geteilter Städte im Baltikum (Haparanda-Tornio, Narwa-Iwangorod und Valga/Valka) sollten Faktoren herausgestellt werden, die das räumliche Verhalten der Bewohner in den Grenzagglomerationen bestimmen. Die drei Beispiele stellen sowohl verschiedene geopolitische als auch ethnische Konfigurationen dar. Grenztheorie wird als Teil einer allgemeinen Interaktionstheorie diskutiert, in der die homogenisierende Rolle des Staates mit den Interaktionsmöglichkeiten der im Grenzraum lebenden Individuen kontrastiert wird. Im Fall von Haparanda-Tornio wird eine homogene Bevölkerung auf der finnischen Seite einer ethnisch mehr divergierenden Verteilung im schwedischen Haparanda gegenübergestellt. Einwanderer aus Finnland zeigen ein nach Finnland gerichtetetes räumliches Verhalten, weil zweisprachige Bewohner eine brückenbauende Rolle spielen. In Narwa-Iwangorod bewohnt dieselbe russische Ethnie beide Seiten, aber geopolitische Beschränkungen hemmen die lokale grenzüberschreitende Interaktion. Valga/Valka ist nach ethnischen Kriterien geteilt, und es gibt wenige Gründe und Möglichkeiten, die Grenze zu überschreiten, mit Ausnahme der russisch sprechenden Bevölkerung, für welche der Grenzübergang jedoch formal schwierig ist. Die alten und neuen internen EU-Grenzen beeinflussen in ethnischer und linguistischer Hinsicht die Aktions- und Kommunikationsräume der Einwohner. Die EU-Aus- sengrenze beschränkt die Möglichkeiten der lokalen grenzüberschreitenden Interaktion, selbst wenn die Bevölkerung derselben ethnischen Gruppe angehört.

Résumé: Agglomérations frontalières de la Baltique: obstacles et opportunités pour les interactions locales L'article se donne pour objectif d'évaluer les facteurs qui influencent le comportement spatial des habitants des agglomérations frontalières et leur situation géopolitique dans trois villes-frontières de la Baltique: Haparanda-Tornio, Narva-Ivangorod et Valga/Valka. Ces trois cas d'étude se trouvent dans des configurations géopolitiques et ethniques différentes. La théorie des frontières est ici considérée comme une théorie de l'interaction, avec un accent particulier porté sur le rôle homogénéisant de l'Etat, lequel contraste avec les interactions des individus vivant dans les zones frontalières. Dans le cas de Haparanda-Tornio, l'homogénéité de la population de la partie finlandaise contraste avec la composition plus hétérogène de la partie suédoise de Haparanda. Les migrants venus de Finlande se tournent vers leur pays d'origine, alors que les populations locales, particulièrement bilingues, oeuvrent comme des "passeurs» à travers les frontières. A Narva-Ivangorod, la même population russe peuple les deux côtés de la frontière, mais les interdictions légales limitent les interactions transfrontalières. Valga/Valka, en revanche, est divisée selon des critères ethniques. Il en résulte peu de motivations transfrontalières, exception faite des russophones qui éprouvent cependant de grandes difficultés légales à se rendre de l'autre côté de la frontière. Les frontières internes de l'Union européenne (UE), récentes et anciennes, permettent à des facteurs ethniques et linguistiques d'influencer l'action et la communication des habitants. Les frontières externes, elles, entravent les possibilités d'interactions transfrontalières, même si la population appartient à un même groupe.

Prof. Dr. Thomas Lundén, Center for Baltic and East European Studies, Södertörn University College, SE14189 Huddinge, Sweden.

e-mail: thomas.lunden@sh.se

Manuskripteingang/received/manuscrit entré le 11.7.2006

Annahme zum Druck/accepted for publication/accepté pour l'impression: 25.2.2007 